UniversitätsSpital Zürich

Dermatologische Klinik

Prof. Dr. med. R. Dummer

Arbeit unter Leitung von Dr. med. M. Nägeli

\title{
Nevoid Basal Cell Carcinoma Syndrome - Report from the Zurich Nevoid Basal Cell Carcinoma Syndrome Cohort
}

\author{
INAUGURAL-DISSERTATION \\ zur Erlangung der Doktorwürde der Humanmedizin \\ der Medizinischen Fakultät \\ der Universität Zürich
}

\author{
vorgelegt von \\ Susanne Dorothea Linda Rehefeldt-Erne
}

Genehmigt auf Antrag von Prof. Dr. med. R. Dummer Zürich 2016 


\section{Publikationshinweis}

Nevoid Basal Cell Carcinoma Syndrome - Report from the Zurich Nevoid Basal Cell Carcinoma Syndrome Cohort

Publiziert am: $\quad$ 08. April, 2016

Journal:

Im Dermatology; www.karger.com/Article/Abstract/444792 


\title{
Nevoid Basal Cell Carcinoma Syndrome: Report from the Zurich Nevoid Basal Cell Carcinoma Syndrome Cohort
}

\author{
Susanne Rehefeldt-Erne Mirjam C. Nägeli Nina Winterton Lea Felderer \\ Lisa Weibel Jürg Hafner Reinhard Dummer \\ Department of Dermatology, University Hospital Zurich, Zurich, Switzerland
}

\section{Key Words}

Gorlin-Goltz syndrome · Nevoid basal cell carcinoma syndrome $\cdot$ Basal cell carcinoma Jaw cysts

\begin{abstract}
Background: Nevoid basal cell carcinoma syndrome (NBCCS, Gorlin-Goltz syndrome) presents various symptoms and can disfigure patients. The estimated prevalence is around 1:100,000. Objective: To systematically investigate the clinical manifestations of NBCCS patients of the Zurich register and compare them with those described in 4 epidemiological studies performed in other countries. Methods: We analyzed patient characteristics and clinical manifestations in a register of 30 NBCCS patients in Zurich, Switzerland. We compared our findings to the results of 4 epidemiological studies performed in America, Australia, Japan and the UK. Results: We obtained information concerning basal cell carcinomas (BCCs) and jaw cysts from 28 patients out of our population of 30 NBCCS patients. The mean age at onset of the first BCC was 24 years, and the mean age at diagnosis of the first jaw cyst was 15.6 years. The average number of jaw cysts was 8.4 ; the average number of BCCs was $207.72 .5 \%$ of the examined BCCs showed a nodular histology, but we also found scirrhous and superficial types. Conclusion: The dis-
\end{abstract}

\section{KARGER}

E-Mail karger@karger.com

www.karger.com/drm ease burden associated with NBCCS diagnosed in Swiss patients is significant and comparable to that of other countries. Regular skin examination and oromaxillary examinations should be performed early in diagnosis, and patients should undergo early UV protection. Nodular BCC is the most common BCC subtype in this patient population.

(c) 2016 S. Karger AG, Basel

\section{Introduction}

The nevoid basal cell carcinoma syndrome (NBCCS) was first described by Gorlin and Goltz in their article 'Multiple nevoid basal-cell epithelioma, jaw cysts and bifid rib. A syndrome', published in the New England Journal of Medicine in 1960 [1]. The NBCCS - also referred to as Gorlin-Goltz syndrome - describes an autosomal dominant disease characterized by a variety of developmental disorders and neoplasias, especially basal cell carcinomas (BCCs) at younger ages. The prevalence is estimated from 1:31,000 [2] up to 1:256,000 [3]. Based on these prevalence rates, the NBCCS population in Switzerland would be estimated to be $32-266$ based on a population of $8,237,700$ inhabitants [4]. NBCCS is most commonly caused by a genetic mutation in the gene PTCH1 - 
Fig. 1. Orthopantomogram showing odontogenic keratocysts (arrows) in one of our patients.

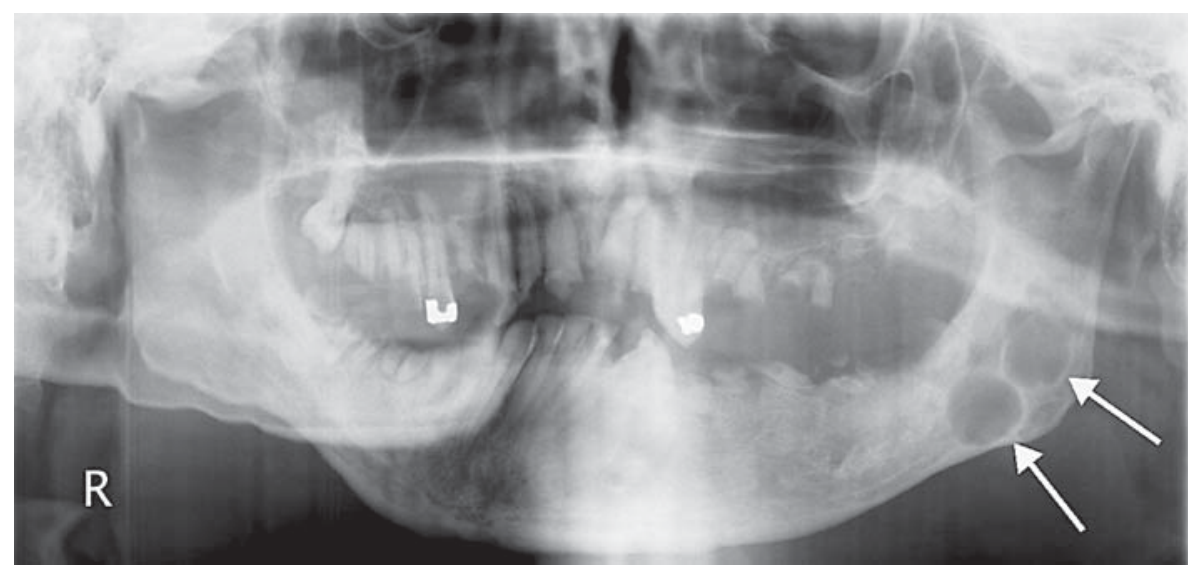

a suppressor of the hedgehog pathway, which leads to the activation of smoothened. Smoothened inhibitors (like vismodegib) represent new treatment options for advanced BCC, especially in cases in which the NBCCS causes enormous damage and disfigurement in patients [5]. PTCH1 mutations cannot be identified in every case with the clinical findings typical of NBCCS. Wicking et al. [6] showed PTCH protein mutations in 28 of 71 cases, $86 \%$ being truncations of the protein. The same study could not indicate a correlation between genotype and phenotype. A more recent study by Smith et al. [7] reported the presence of a missense mutation, an exon copy number deletion and nonsense mutation in SUFU (suppressor of fused), a repressor of the sonic hedgehog ( $\mathrm{SHH}$ ) pathway in NBCCS patients without PTCH1 mutations.

Life expectancy with NBCCS is 73.4 years and is significantly lower than that of a healthy population in the Western world [8]. However, compared to other hereditary cancer disorders such as neurofibromatosis 1, neurofibromatosis 2, familial adenomatous polyposis and von Hippel-Lindau syndrome, NBCCS is associated with the smallest reduction in life expectancy. Although only 19\% of the patient deaths are caused by an attribute of the syndrome, NBCCS can negatively impact life quality to a considerable degree [8]. Therefore, further study is needed to increase life quality and life expectancy of NBCCS patients.

As there is no single symptom or sign supporting diagnosis, a positive diagnosis is defined to include either 1 major criterion plus molecular confirmation, 2 major criteria or 1 major plus 2 minor criteria [9]. Major criteria include: multiple BCCs or early incidence of BCCs (under the age of 20), keratocysts of the jaw (fig. 1), palmar/plantar pits, calcification of the falx (fig. 2), rib anomalies, ovarian fibromas, medulloblastomas, phalangeal flame-

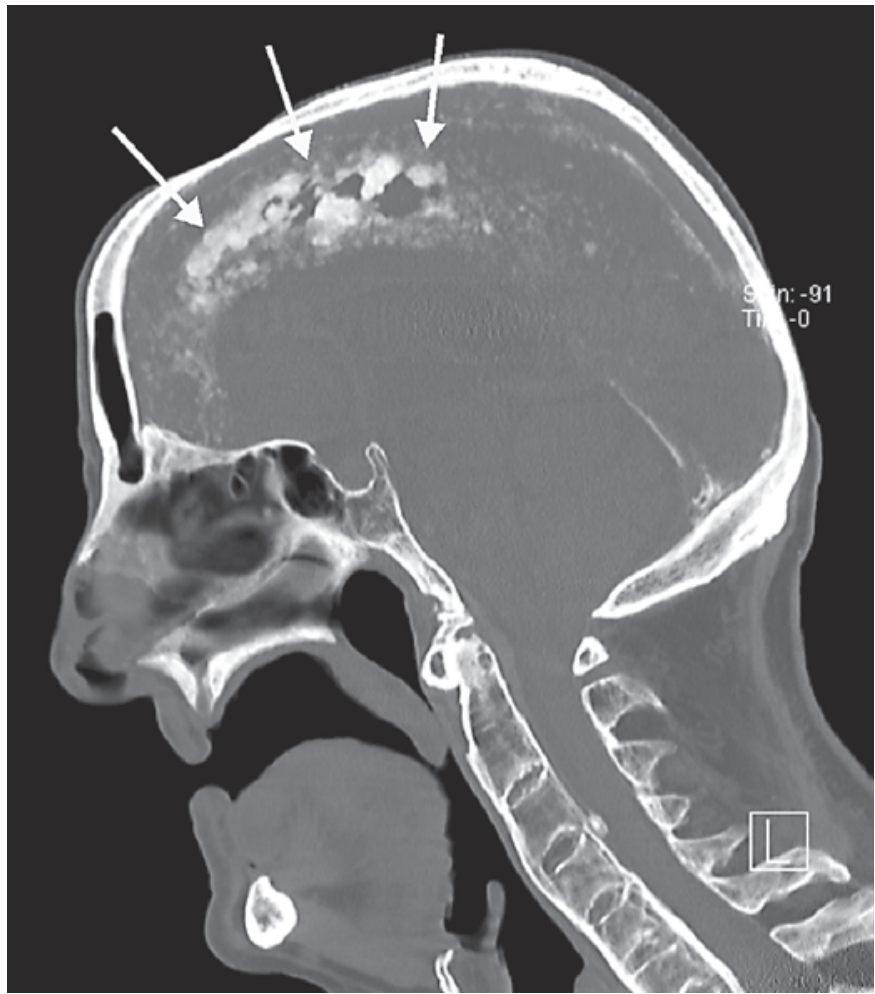

Fig. 2. Computer tomogram showing calcification of the falx cerebri (arrows) in one of our patients.

shaped lucencies and brachymetacarpalism in all 4 limbs. Having a first-degree relative with NBCCS is also considered a major criterion [10]. Minor criteria include: spina bifida occulta or vertebral anomalies, brachymetacarpalism in 1 limb, hypertelorism and frontal bossing. Table 1 shows the major and minor criteria for the diagnosis of NBCCS. 


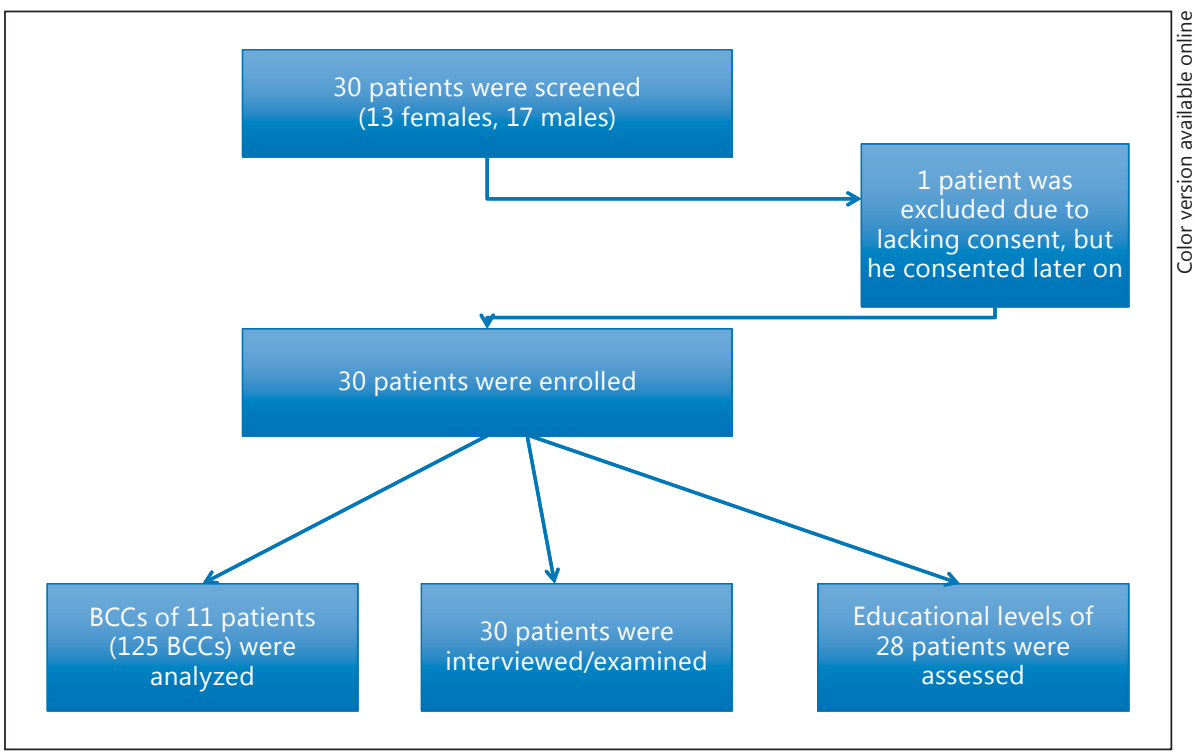

Fig. 3. Flowchart of the Methods.

Table 1. Major and minor criteria as suggested by Bree et al. [9]

\begin{tabular}{|c|c|}
\hline Major criteria & Minor criteria \\
\hline \multirow{2}{*}{$\begin{array}{c}\text { BCC }<20 \text { years or excessive } \\
\text { numbers of BCCs }\end{array}$} & Rib anomalies \\
\hline & Other specific skeletal \\
\hline Jaw cyst $<20$ years & malformations and \\
\hline Palmar or plantar pitting & radiological anomalies \\
\hline \multirow{2}{*}{$\begin{array}{l}\text { Calcification of the falx } \\
\text { cerebri }\end{array}$} & Macrocephaly \\
\hline & Cleft lip or palate \\
\hline \multirow{2}{*}{$\begin{array}{l}\text { Medulloblastoma, typically } \\
\text { desmoplastic }\end{array}$} & Cardiac or ovarian fibroma \\
\hline & Lymphomesenteric cysts \\
\hline $\begin{array}{l}\text { First-degree relative with } \\
\text { NBCCS }\end{array}$ & $\begin{array}{l}\text { Eye anomalies (strabismus, } \\
\text { hypertelorism, congenital } \\
\text { cataract, glaucoma, } \\
\text { coloboma) }\end{array}$ \\
\hline
\end{tabular}

The following images illustrate the major criteria.

American, British, Australian and Japanese epidemiological studies investigated the frequency and clinical manifestations of NBCCS [10-13]. The results of these studies differ in some aspects, including age of incidence of first BCCs and jaw cysts and the frequency of other clinical symptoms. So far there has not been any comparable study in Central Europe. In addition to better understanding NBCCS patient characteristics, we were also interested in the typical subtype of BCCs in NBCCS. Thus, we undertook an analysis of NBCCS patient characteristics and clinical manifestations in a register of 30 NBCCS patients in Zurich, Switzerland, and compared our results to studies from international populations. We note that some of the patients in our study were recruited through a self-help group in Germany.

\section{Methods}

For further details, see the supplementary materials (for all online suppl. material, see www.karger.com/doi/10.1159/000444792) [9] (fig. 3).

\section{Results}

The study population consisted of 13 female and 17 male patients. The average age was 41.5 years $( \pm 18.7$ years), and the median was 38.5 years. 28 patients were Caucasian, 2 first-degree related patients were AfroAmerican (table 2). There was 1 family consisting of a mother and her 2 sons, and another female patient and her daughter were included. Of the 30 studied patients, we assessed the educational levels of 28 . Of these patients, 11 had a low level of education (1 security man, 1 logistician, 1 employee of a mountain railway, 1 employee of a repair shop, 1 saleswoman, 2 warehouse clerks, 1 elderly care nurse, 1 day laborer, 1 chef), 10 an intermediate level (4 nurses, 1 locomotive driver, 1 musician, 1 IT administrator, 2 officials, 1 head of logistics), and 3 patients were considered as highly educated (1 IT engineer, 1 student, 1 software engineer). 
Fig. 4. Clinical manifestation in different age categories. Jaw cysts = keratocysts of the jaw; pits = palmoplantar hyperkeratosis.

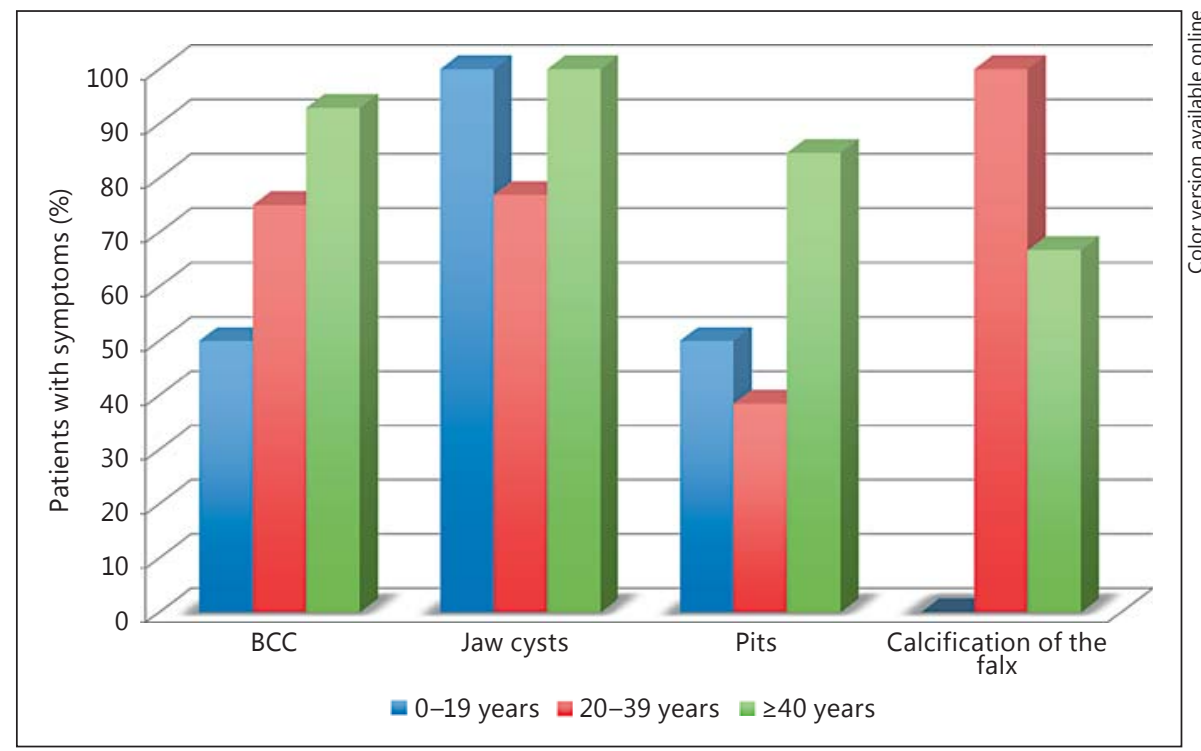

Table 2. Comparison of clinical manifestations of the NBCCS

\begin{tabular}{|c|c|c|c|c|c|}
\hline & $\begin{array}{l}\text { Evans et al. } \\
\text { [11] (UK) }\end{array}$ & $\begin{array}{l}\text { Shanley et al. } \\
\text { [12] (Australia) }\end{array}$ & $\begin{array}{l}\text { Kimonis et al. } \\
{[10] \text { (USA) }}\end{array}$ & $\begin{array}{l}\text { Endo et al. } \\
\text { [13] (Japan) }\end{array}$ & $\begin{array}{l}\text { This study } \\
\text { (Switzerland) }\end{array}$ \\
\hline Patients, $\mathrm{n}$ & 84 & 118 & 105 & 157 & 30 \\
\hline Mean age, years & n.a. & 35 & 34.5 & 33.1 & 41.5 \\
\hline Gender M:F & $1: 1.3$ & $1: 1.3$ & $1: 1.2$ & $1.1: 1$ & $1: 0.76$ \\
\hline Patients with BCC & $33 / 70(47)$ & $90 / 118(76)$ & $71 / 90(80)$ & $56 / 148(37.8)$ & $23 / 28(82.11)$ \\
\hline Age $>20$ years & $33 / 45(73)$ & $71 / 84(85)$ & $58 / 64(91)$ & $53 / 103(51.4)$ & $21 / 25(84)$ \\
\hline Age $>40$ years & $19 / 21(90)$ & $35 / 37(95)$ & $34 / 35(97)$ & $33 / 46(71.7)$ & $11 / 12(91.7)$ \\
\hline Mean age at first BCC, years & n.a. & 20.3 & 21.4 & 37.4 & 24 \\
\hline Patients with jaw cysts & $46 / 70(66)$ & $85 / 113(75)$ & $78 / 105(74)$ & $126 / 146(86.3)$ & $25 / 28(89.3)$ \\
\hline Age $>20$ years & $37 / 45(82)$ & $66 / 82(80)$ & $60 / 74(81)$ & $92 / 101(91.1)$ & $23 / 26(88.5)$ \\
\hline Age $>40$ years & $19 / 21(90)$ & $25 / 35(71)$ & $29 / 38(76)$ & $32 / 39(82)$ & $13 / 13(100)$ \\
\hline Mean number of jaw cysts per patient & n.a. & $1-28(6)$ & $1-28(5.1)$ & $1-10(3.68)$ & $0-50(8.4)$ \\
\hline Mean age at first jaw cyst, years & n.a. & 15.5 & 17.3 & 19.8 & 15.6 \\
\hline Patients with pitting & $50 / 70(71)$ & $82 / 103(80)$ & $89 / 102(87)$ & $86 / 143(60.1)$ & $17 / 28(60.7)$ \\
\hline Patients with cleft lip/palate & $4 / 70(5)$ & $4 / 107(4)$ & $3 / 103(3)$ & $12 / 133(9)$ & $3 / 27(11.1)$ \\
\hline Calcification of falx cerebri & n.a. & $81 / 89(92)$ & $53 / 82(65)$ & $78 / 98(79.6)$ & $11 / 13(84.6)$ \\
\hline Patients with medulloblastoma & $3 / 84(4)$ & $1 / 118(1)$ & $4 / 105(4)$ & $4 / 120(3.3)$ & 0 \\
\hline Patients with ovarian fibroma & $6 / 25(24)$ & $9 / 63(14)$ & $9 / 52(17)$ & $5 / 40(12.5)$ & $1 / 12(8.3)$ \\
\hline
\end{tabular}

Figures in parentheses are percentages. n.a. = Not assessed.

There were 2 patients still attending school and 2 disabled patients.

In summary, $46 \%$ of the patients had a low level of education, $42 \%$ an intermediate level and only $12 \%$ a high level of education.

In the youngest age class (0-19 years), very few participants exhibited BCC, but the second youngest patient group (20-39 years) displayed a greater percentage of jaw cysts than BCC (fig. 4). The average age at onset of the first jaw cyst in this study was 15.6 years which is rather young compared to other studies. Dentists and oral surgeons should consider the diverse NBCCS, when confronted with a keratocyst of the jaw.

$84 \%$ of the patients over 20 years old showed BCC. The average age at the first diagnosis of BCC was 24 years (table 2).

In patients with NBCCS, the BCCs occur predominantly in UV-exposed areas such as the face. But BCC 


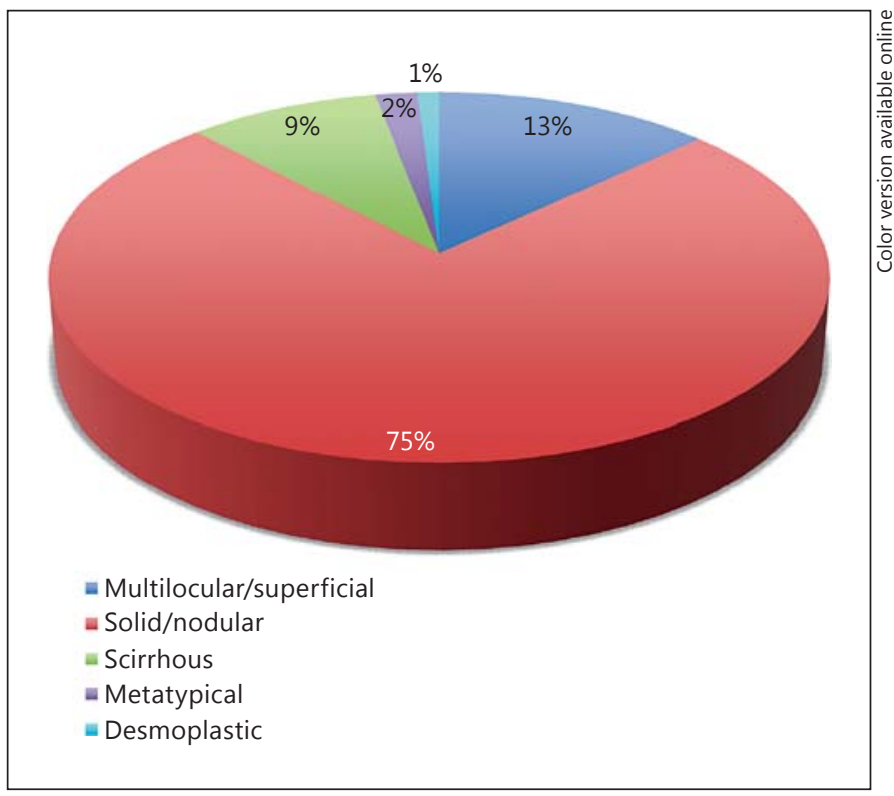

Fig. 5. BCC subtypes found in the NBCCS patients examined.

may also occur in non-UV-exposed areas. In the current study $80 \%$ of the BCCs were located in UV-exposed areas. The majority of the histologically examined BCCs were nodular (75\%; fig. 5).

A calcification of the falx cerebri was found or had been reported in $84.6 \%$ of the cases. Due to the patients' high sensitivity to radiation, no additional radiographs were made [14]. Additional MRI examinations could not be realized due to the costs.

Palmar or plantar pitting was present in $60.7 \%$ of the patients and a cleft lip or palate in $11.1 \%$.

Besides the BCC there are additional neoplasias associated with the NBCCS. Associations are well established for medulloblastoma, meningioma and ovarian and cardiac fibromas. In our patient cohort there was no medulloblastoma even though the niece of 1 patient was diagnosed with a medulloblastoma at the age of 2 months. One of the 12 female patients had an ovarian fibroma. Three of the female patients reported myomas, a polycystic ovary and an ovarian cyst, respectively. One male patient suffered from the very rare cardiac fibroma. No additional echocardiographies were performed. Two patients suffered from meningioma, and there were 5 cases of other neoplasias, including non-Hodgkin lymphoma, prostate cancer, microadenoma of the pituitary gland, carcinoma of the sigmoid colon, a mammary tumor and a neurinoma.

Gorlin-Goltz Syndrome in Switzerland
Ophthalmological disorders such as cataract, coloboma and microphthalmos can occur [11]. In this study $25 \%$ of the patients had ophthalmological disorders (e.g. cataract, detached retina with cataract, a rubeosis iridis and an orbital exenteration and unexplained blindness in 1 eye). $50 \%$ of the patients had a first-degree relative with known NBCCS.

\section{Discussion}

It has been suggested that there is a need for a genetic register which would facilitate disease screening, thus leading to earlier diagnosis and follow-up and ultimately improved patient survival [15]. More recently, improved survival of patients with hereditary cancers has been demonstrated in association with the establishment of such a genetic register, emphasizing the need for this type of registries [8].

Four major studies investigated the clinical presentations of NBCCS. These studies were performed on populations in the UK [11], Australia [12], the USA [10] and Japan [13].

The aim of our study was to investigate the clinical presentations of NBCCS in a patient group in Zurich, Switzerland, and to compare our results to international data. In addition, we were especially interested in the histological subtypes of BCC associated with the NBCCS. Our data show that all BCC subtypes are found in NBCCS patients, with nodular and superficial BCCs being the most common ones (fig. 5). Nodular BCC is also the most common type of BCC in the general population as well as in NBCCS patients. Wrone et al. [16] examined the frequency of different BCC subtypes seen in dermatology clinics in a Veterans Affairs health care system in the USA and reported that $63.1 \%$ of BCC cases were nodular and $10.7 \%$ superficial. An even higher rate of the nodular subtype of BCC was reported by Scrivener et al. [17]. These authors analyzed BCC cases diagnosed at a single center of dermatopathology from 1967 to 1996 and found that $78.7 \%$ of the cases were nodular, $15.1 \%$ superficial and $6.2 \%$ morpheiform. Dreier et al. [18] analyzed the frequency of complicated BCC cases and found that from more than 2,000 BCCs $6.6 \%$ were moderate (4-9 BCCs in 5 years, relapse/complications/hospitalizations during investigated years) and $0.6 \%$ were severe (extended $/ \mathrm{met}$ astatic disease with $>10$ BCCs or need for extensive treatment). Patients with moderate or severe BCCs may particularly benefit from new therapeutic options. 

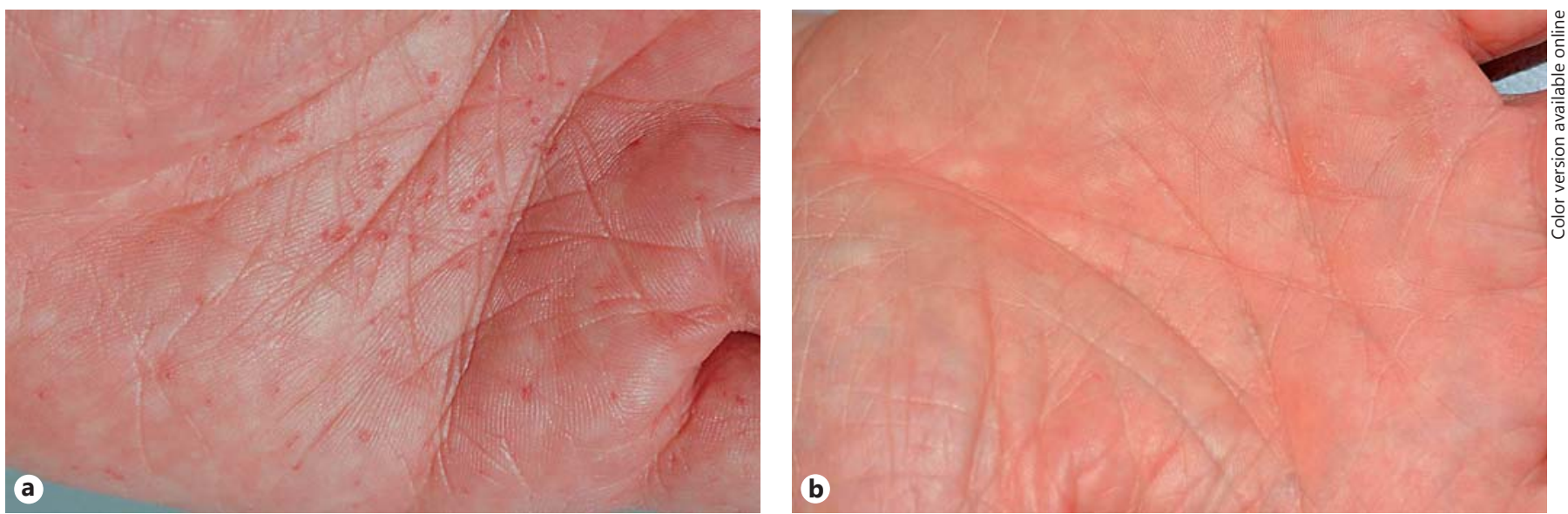

Fig. 6. a Palmar pits before starting the smoothened inhibitor therapy with LEQ-506 (Novartis) in August 2006. b Complete disappearance of the pits in the same patient in February 2015, 3 months after termination of the therapy.

Given the considerable variety of the NBCCS symptoms, the frequencies of major and minor criteria observed are surprisingly similar compared with international results [10], but there are some distinct and interesting differences between the various reports.

Japanese patients seem to have a reduced frequency of BCCs and develop BCCs later in life (37.4 years) [13]. We assume this peculiarity to be due to genetic differences. Nevertheless, the sun-avoiding habits of the Japanese could play a role as well. In Switzerland, $84 \%$ of the patients over the age of 20 had 1 or more BCCs. This is within the range of other nations even though the British patients over 20 years showed a lower frequency of $73 \%$ [11]. The mean age incidence of the first BCC in Switzerland (24 years) is similar to that in the USA and Australia. The high overall incidence of BCCs in the USA and Australia could be caused by the tanning habits of the Americans and the intense UV irradiation in Australia along with the predominance of fair skin types in both countries $[10,12]$. According to our findings, $80 \%$ of the BCCs of NBCCS patients were located in UVexposed parts of the body; consequently, doctors and pediatricians should brief their NBCCS patients on UV protection very early in life. Interestingly, all BCC subtypes were found which suggests that $\mathrm{SHH}$ signaling is relevant for all BCC types.

Odontogenic keratocysts are an important major criterion and have been reported in some studies as even more prevalent than BCCs. Nevertheless, patients with SUFU mutation show a 20 times higher risk of medul- loblastoma than patients with PTCH1 mutations [7]. Compared with international results, Japan has the highest prevalence of jaw cysts at 91.1\% [13]. Our study showed a high frequency of jaw cysts $(89.3 \%)$ and the lowest mean age at the diagnosis of the first jaw cyst (15.6 years). There might be a slight bias in the low age at discovery of jaw cysts because some of the patients in this study were referred by oral surgeons. However, the young age and high prevalence of jaw cysts underline the importance of regular and early radiological and dental examinations.

The frequency of palmar and plantar pitting varied from $60.2 \%$ in our study group up to $87 \%$ in the American study; this latter observation no doubt contributes to the American authors' belief in pitting as a useful diagnostic criterion [10]. According to Shanley et al. [12], the pitting was rather palmar than plantar and was more clearly visible after a water bath. In one of our NBCCS patients who underwent therapy with a smoothened inhibitor, we saw a complete disappearance of the palmar pits (fig. 6).

Cleft lip or palate occurred in the Swiss group in $11.1 \%$ of cases, which is more frequent than in all other reports. Japan was closest to the results of Switzerland with 9\% [13]. The remaining studies showed a prevalence of $3-5 \%$.

In our study, calcification of the falx cerebri was found in 11 of 13 patients with a radiograph (84.6\%) which is less often than in other studies. This is possibly attributable to the fact that no additional radiographs in the Swiss and Japanese study settings have been undertaken. 
Only 1 female patient was documented with an ovarian fibroma. In the British study, up to every fourth female patient had an ovarian fibroma [11]. It is important to detect ovarian fibromas even if they are benign in order to anticipate the threat of an ovarian torsion and infarction and to prevent severer consequences [11].

Ophthalmological disorders were rather rare, whereas in the British study $26 \%$ of the patients had eye problems such as strabismus, nystagmus, cataract and microphthalmia [11]. In the American study 19\% of patients showed a strabismus [10].

$50 \%$ of the Swiss patients had a first-degree relative with a known NBCCS, which is similar to the findings of the Japanese study with $48.4 \%$.

Our study is the first systematic collection of patients with NBCCS in continental Europe. It describes the results from the early stages of the Zurich Register of Gorlin-Goltz Patients.

The number of patients included in this study was limited. Bias existed due to the inclusion of subjects who had been taking part in hedgehog inhibitor trials.

Precise declaration of the number of BCCs represents another difficulty because three-digit numbers are hard to recall for patients. A similar problem arises when collecting data concerning numbers of BCCs in UV-exposed versus nonexposed areas.

In order to obtain exact numbers of skeletal abnormalities like anomalies of the ribs, vertebrae and metacarpals, a systematic radiological examination of the skull, chest and spine plus the hands and feet would be necessary; however, this is a delicate matter with patients who have a tendency to develop BCCs in radiation-exposed areas.

A further aspect which will be examined is the correlation between genotype and phenotype. We collected samples of blood and BCC tissue of most of our patients in order to examine this correlation in a future study.

\section{Conclusion}

The disease burden associated with NBCCS in Swiss patients is significant and comparable to other countries.

The international consensus statement concerning the surveillance guidelines covers the important symptoms seen in our patients as well as in other studies [9]. Although the first BCCs show only later in life (in our study the average age is 24), regular skin examinations should be considered. UV protection early in life is extremely important.

Gorlin-Goltz Syndrome in Switzerland
In our study as well as in another, some patients had their first jaw cyst over the age of 20 years [19]. Therefore, we would suggest undertaking repeated oromaxillary examinations after the first 2 decades. Due to the sensitivity of NBCCS patients to radiation, MRI examinations should be discussed.

There are many unknown or little understood variables in this syndrome. Little is known about the correlation between genotype and phenotype. While some authors have seen no such correlation, others have observed very significant ones $[6,7]$. Therefore, this correlation should be examined more thoroughly.

In 2012, the first oral smoothened inhibitor vismodegib was approved for treatment of BCC. Vismodegib has been shown to achieve significant tumor regressions including complete responses in locally advanced and metastatic BCC [5, 20-22]. The rate of low-grade adverse events (e.g. muscle spasms, alopecia, disgeusia, weight loss, asthenia) is substantial, but the documented improvement or preservation of quality of life for treated patients makes vismodegib a novel therapeutic modality with a positive benefit-to-risk ratio for patients with advanced BCC $[23,24]$.

Vismodegib shrinks some keratocystic odontogenic tumors of the jaw in patients with NBCCS and may offer an alternative to surgical therapy [25]. This smoothened inhibitor-induced tumor regression is accompanied by a dynamic change of the microenvironment with a disruption of immune privilege involving an influx of cytotoxic $T$ cells, activation of the adaptive immune functions, and a profound alteration of the local chemokine/cytokine network [26].

Familial predisposition to medulloblastoma is well known to occur in association with germline mutations of $P T C H 1$ in patients with NBCCS. In some medulloblastoma patients, a germline mutation has been discovered in SUFU, a repressor in the SHH pathway. Thus, inhibiting the $S H H$ signaling pathway is an ideal candidate therapy for medulloblastoma $[27,28]$.

This is the first systematic collection of patients with NBCCS in Switzerland. The clinical manifestations associated with NBCCS in Swiss patients are comparable to those of other countries. Recruitment of more patients would be beneficial to study this disease.

\section{Statement of Ethics}

The authors have no ethical conflicts to disclose. 


\section{Disclosure Statement}

There are no conflicts of interest connected to this work. Prof. Dummer receives research funding from Novartis, Merck Sharp \&
Dhome, Bristol-Myers Squibb, Roche, GlaxoSmithKline and has a consultant or advisory board relationship with Novartis, Merck Sharp \& Dhome, Bristol-Myers Squibb, Roche, GlaxoSmithKline, and Amgen outside the submitted work.

\section{References}

1 Gorlin RJ, Goltz RW: Multiple nevoid basalcell epithelioma, jaw cysts and bifid rib. A syndrome. N Engl J Med 1960;262:908-912.

2 Evans DG, Howard E, Giblin C, Clancy T, Spencer H, Huson SM, Lalloo F: Birth incidence and prevalence of tumor-prone syndromes: estimates from a UK family genetic register service. Am J Med Genet A 2010; 152A:327-332.

3 Lo Muzio L, Nocini PF, Savoia A, Consolo U, Procaccini M, Zelante L, Pannone G, Bucci P, Dolci M, Bambini F, Solda P, Favia G: Nevoid basal cell carcinoma syndrome. Clinical findings in 37 Italian affected individuals. Clin Genet 1999;55:34-40.

4 http://www.bfs.admin.ch/bfs/portal/de/in$\mathrm{dex} /$ themen/01/02/blank/key/bevoelkerungsstand.html.

5 Tang JY, Mackay-Wiggan JM, Aszterbaum M, Yauch RL, Lindgren J, Chang K, Coppola C, Chanana AM, Marji J, Bickers DR, Epstein $\mathrm{EH}$ : Inhibiting the hedgehog pathway in patients with the basal-cell nevus syndrome. $\mathrm{N}$ Engl J Med 2012;366:2180-2188.

6 Wicking C, Shanley S, Smyth I, Gillies S, Negus K, Graham S, Suthers G, Haites N, Edwards $\mathrm{M}$, Wainwright $\mathrm{B}$, Chenevix-Trench G: Most germ-line mutations in the nevoid basal cell carcinoma syndrome lead to a premature termination of the patched protein, and no genotype-phenotype correlations are evident. Am J Hum Genet 1997;60:21-26.

7 Smith MJ, Beetz C, Williams SG, Bhaskar SS, O'Sullivan J, Anderson B, Daly SB, Urquhart JE, Bholah Z, Oudit D, Cheesman E, Kelsey A, McCabe MG, Newman WG, Evans DG: Germline mutations in SUFU cause Gorlin syndrome-associated childhood medulloblastoma and redefine the risk associated with PTCH1 mutations. J Clin Oncol 2014;32: 4155-4161.

8 Wilding A, Ingham SL, Lalloo F, Clancy T, Huson SM, Moran A, Evans DG: Life expectancy in hereditary cancer predisposing diseases: an observational study. J Med Genet 2012;49:264-269.

9 Bree AF, Shah MR; BCNS Colloquium Group: Consensus statement from the first international colloquium on basal cell nevus syndrome (BCNS). Am J Med Genet A 2011; 155A:2091-2097.

10 Kimonis VE, Goldstein AM, Pastakia B, Yang ML, Kase R, DiGiovanna JJ, Bale AE, Bale SJ: Clinical manifestations in 105 persons with nevoid basal cell carcinoma syndrome. Am J Med Genet 1997;69:299-308.
11 Evans DG, Ladusans EJ, Rimmer S, Burnell LD, Thakker N, Farndon PA: Complications of the naevoid basal cell carcinoma syndrome: results of a population based study. J Med Genet 1993;30:460-464.

12 Shanley S, Ratcliffe J, Hockey A, Haan E, Oley C, Ravine D, Martin N, Wicking C, ChenevixTrench G: Nevoid basal cell carcinoma syndrome: review of 118 affected individuals. Am J Med Genet 1994;50:282-290.

13 Endo M, Fujii K, Sugita K, Saito K, Kohno Y, Miyashita T: Nationwide survey of nevoid basal cell carcinoma syndrome in Japan revealing the low frequency of basal cell carcinoma. Am J Med Genet A 2012;158A:351357.

14 Wright AT, Magnaldo T, Sontag RL, Anderson LN, Sadler NC, Piehowski PD, Gache Y, Weber TJ: Deficient expression of aldehyde dehydrogenase $1 \mathrm{~A} 1$ is consistent with increased sensitivity of Gorlin syndrome patients to radiation carcinogenesis. Mol Carcinog 2015;54:473-484.

15 Mallinson EK, Newton KF, Bowen J, Lalloo F, Clancy T, Hill J, Evans DG: The impact of screening and genetic registration on mortality and colorectal cancer incidence in familial adenomatous polyposis. Gut 2010;59:13781382.

16 Wrone DA, Swetter SM, Egbert BM, Smoller $\mathrm{BR}$, Khavari PA: Increased proportion of aggressive-growth basal cell carcinoma in the Veterans Affairs population of Palo Alto, California. J Am Acad Dermatol 1996;35:907910.

17 Scrivener Y, Grosshans E, Cribier B: Variations of basal cell carcinomas according to gender, age, location and histopathological subtype. Br J Dermatol 2002;147:41-47.

18 Dreier J, Cheng PF, Bogdan Alleman I, Gugger A, Hafner J, Tschopp A, Goldinger SM, Levesque MP, Dummer R: Basal cell carcinomas in a tertiary referral centre: a systematic analysis. Br J Dermatol 2014;171:1066-1072.

19 Bronoosh P, Shakibafar AR, Houshyar M, Nafarzade S: Imaging findings in a case of Gorlin-Goltz syndrome: a survey using advanced modalities. Imaging Sci Dent 2011;41: 171-175.

20 Von Hoff DD, LoRusso PM, Rudin CM, Reddy JC, Yauch RL, Tibes R, Weiss GJ, Borad MJ, Hann CL, Brahmer JR, Mackey HM, Lum BL, Darbonne WC, Marsters JC, de Sauvage FJ, Low JA: Inhibition of the hedgehog pathway in advanced basal-cell carcinoma. N Engl J Med 2009;361:1164-1172.
21 Sekulic A, Migden MR, Oro AE, Dirix L, Lewis $\mathrm{KD}$, Hainsworth JD, Solomon JA, Yoo S, Arron ST, Friedlander PA, Marmur E, Rudin CM, Chang AL, Low JA, Mackey HM, Yauch RL, Graham RA, Reddy JC, Hauschild A: Efficacy and safety of vismodegib in advanced basal-cell carcinoma. N Engl J Med 2012;366: 2171-2179.

22 Dreier J, Dummer R, Felderer L, Nägeli M, Gobbi S, Kunstfeld R: Emerging drugs and combination strategies for basal cell carcinoma. Expert Opin Emerg Drugs 2014;19:353-365.

23 Basset-Seguin N, Hauschild A, Grob JJ, Kunstfeld R, Dréno B, Mortier L, Ascierto PA, Licitra L, Dutriaux C, Thomas L, Jouary T, Meyer N, Guillot B, Dummer R, Fife K, Ernst DS, Williams S, Fittipaldo A, Xynos I, Hansson J: Vismodegib in patients with advanced basal cell carcinoma (STEVIE): a pre-planned interim analysis of an international, open-label trial. Lancet Oncol 2015;16:729-736.

24 Migden MR, Guminski A, Gutzmer R, Dirix L, Lewis KD, Combemale P, Herd RM, Kudchadkar R, Trefzer U, Gogov S, Pallaud C, Yi T, Mone M, Kaatz M, Loquai C, Stratigos AJ, Schulze HJ, Plummer R, Chang AL, Cornélis F, Lear JT, Sellami D, Dummer R: Treatment with two different doses of sonidegib in patients with locally advanced or metastatic basal cell carcinoma (BOLT): a multicentre, randomised, double-blind phase 2 trial. Lancet Oncol 2015;16:716-728.

25 Ally MS, Tang JY, Joseph T, Thompson B, Lindgren J, Raphael MA, Ulerio G, Chanana AM, Mackay-Wiggan JM, Bickers DR, Epstein $\mathrm{EH}$ : The use of vismodegib to shrink keratocystic odontogenic tumors in patients with basal cell nevus syndrome. JAMA Dermatol 2014;150:542-545.

26 Otsuka A, Dreier J, Cheng PF, Nägeli $M$, Lehmann H, Felderer L, Frew IJ, Matsushita S, Levesque MP, Dummer R: Hedgehog pathway inhibitors promote adaptive immune responses in basal cell carcinoma. Clin Cancer Res 2015;21:1289-1297.

27 Brugières L, Remenieras A, Pierron G, Varlet $\mathrm{P}$, Forget $\mathrm{S}$, Byrde V, Bombled J, Puget $\mathrm{S}$, Caron O, Dufour C, Delattre O, Bressac-de Paillerets B, Grill J: High frequency of germline SUFU mutations in children with desmoplastic/nodular medulloblastoma younger than 3 years of age. J Clin Oncol 2012;30: 2087-2093.

28 Archer TC, Weeraratne SD, Pomeroy SL: Hedgehog-GLI pathway in medulloblastoma. J Clin Oncol 2012;30:2154-2156. 


\section{Verdankung und/oder Widmung}

Ich möchte mich in erster Linie bei allen teilnehmenden Patienten für die Mithilfe bedanken.

Zudem gilt meinen Betreuungspersonen Prof. Dr. med. Reinhard Dummer und Dr. med. Mirjam Nägeli ein besonderer Dank.

Ich bedanke mich auch bei Dr. Daniel Varga für seine Unterstützung beim Formatieren der Illustrationen.

Für den ausserordentlichen Rückhalt und die Unterstützung bedanke ich mich herzlich bei meinem Ehemann und meinen Eltern. 


\section{Curriculum Vitae}

\section{Susanne Dorothea Linda Rehefeldt-ERne}

09. 10.1985

$1992-1998$

$1998-2004$

2004

$2004-2007$

2007

$2007-2013$

2013

$2013-2015$

12 / 2015

Seit $01 / 2016$

\author{
Geboren in Basel BS \\ Primarschule Hofmatt in Horw LU \\ Kantonsschule Alpenquai, Luzern \\ Matura, Kantonsschule Alpenquai, Luzern \\ Jusstudium an der Universität Luzern \\ Bachelor of Law, Universität Luzern \\ Medizinstudium an der Universität Fribourg und an der Universität \\ Zürich \\ Master of Medicine an der Universität Zürich \\ Assistenzärztin Innere Medizin, Zuger Kantonsspital, Baar \\ Assistenzärztin Dermatologie, Universitätsspital Zürich \\ Assistenzärztin Lenzmed Gruppenpraxis, Lenzburg AG
}

